\title{
Originalartikel
}

\section{The Writer as a Patient with a Brain Tumour}

\section{A Comparative Study}

\section{Soledad Pereyra}

Institute for Research in Humanities and Social Sciences, National University of La Plata, Argentina solespereyra@googlemail.com

Pereyra, Soledad. (2019). The Writer as a Patient with a Brain Tumour- A Comparative Study Tidsskrift for Forskning i Sygdom og Samfund, nr. 31, 203-219

This article main concern is how professional authors and intellectuals develop illness narratives addressing the experience of having a brain tumour, and how this condition resorts to specific narratological features. Unlike pathographies written by laypersons, autobiographical accounts of illness developed by writers, and intellectuals create a narrative subjectivity that is specifically linked to their professional status rather than to their patient status which is simultaneous with the narrative time. In this article, we analyse two autobiographical novels, addressing the experiences of two European authors and intellectuals suffering from a brain tumour: A Journey Round My Skull (1939[1937]) by Frigyes Karinthy and Until Further Notice, I Am Alive (2012) by Tom Lubbock. These narratives on illness processes related to brain tumours are a place where writers resist the main symptoms and outcomes of this specific disease that, while affecting their cognitive capacities, seem to deprive them of their self-image as writers. Hence, these writings are based on the realignment of their past and present identities (Rimmon-Kenan, 2002: 1518) always in connection with their images as authors. The comparative analysis presented here is intended as a contribution from the field of literary studies to the understanding of subjectivity in patients, whose narratives are not written to seek cure or to search for a 
cause or meaning for the disease, but to fight the loss of the writer-patient creative identity and 'ipseity' (Derrida, 2009).

\section{Introduction}

As suggested by Bishop in The Genius of Disease, a series of brief articles published in 1993-1994, suffering from a brain tumour implies an undeniable fear: during the course of the disease, both patients and their closest relations may start doubting and questioning their thinking (Bishop, 1994). This is what Bishop also defines as an "altered state of consciousness" (Bishop, 1994:2); particularly linked to the specific condition of these patients that can be tracked in their narratives. This distinct symptom and disability indicator of brain tumours are undoubtedly one of the most sensitive ones within patients, that work and define themselves as professional writers and artists, because their capacity for thinking and creating through symbolic languages is in question. In this article, I analyse two autobiographical novels addressing the experiences of two authors and intellectuals suffering from a brain tumour: A Journey Round My Skull (1939[1937]) by Frigyes Karinthy and Until Further Notice, I Am Alive (2012) by Tom Lubbock. Both texts fall into the umbrella term of "illness narratives" as they are "autobiographical accounts of illness spoken or written by patients" (Jurecic, 2012:2).

In his fundamental work Illness Narratives: Suffering, Healing, and the Human Condition (1988), Arthur Kleinman created a paradigm where narratives formulated by patients acquired a central role to produce a detailed clinical image of the patient, and in delving a productive healing relationship. In contrast to writings having illness as their background or topic, illness narratives have the personal illness experience at heart, and they include some grade of factual examination about the outcomes that patients have had on their own lives since diagnosis (Bury, 1982; Frank, 1995).

As the documented research has shown, narratives written by ill and disease subjects are far removed from the brand of autobiographical writings, and form a category of their own (Brody, 1987; Frank, 1995; Hawkins, 1984; Kleinman, 1988). If "life writing" (Bradford, 2009; Preece et al., 2007) has traditionally posed critical questions on the frontiers of literature, illness narratives further reframe this debate. They demand a reflection about the ways of inscribing the ill-self in the narrative, because they frequently avoid countersigning to one specific reading, such as the dominant biomedical one (Frank, 1995). 
As Shapiro has suggested, a patient's story is never "just a story" - this complexifies the narrative defying the reader's expectations of reliability and authenticity (Shapiro 2011). The texts discussed in this article show no ambiguity, alteregos or experimentation with the " $\mathrm{I}$ " figure and voice within the writing. In doing so, they inscribe themselves under the illness narrative concept, which certainly includes biographical and autobiographical accounts of illness (Hawkins, 1999b). Moreover, in our study cases there is a clear identification between the author's name and the main character: the "patient". The narrative in these novels seeks to establish and highlight that the main character, and narrative voice, is both a patient of a disease affecting his cognitive intelligence, and the professional writer whose name is on the book's cover. Since the very beginning of the two books, this identification enables both writer and reader to make an autobiographical reading pact or contract (Lejeune \& Eakin, 1988) based on the equivalence between the two figures and their names (the public writer and the narrator/protagonist), and to explore the implications resulting from this equivalence.

Unlike pathographies, which are mainly developed by laypersons (Hawkins, 1999a), autobiographical accounts of illness, formulated by writers and intellectuals, create a narrative subjectivity specifically linked to their professional status rather than to their patient status, which is simultaneous with the narrative time. In making claims for the relevance of the professional writer as patient within the large corpus of illness narratives, Peter Graham has proposed the concept of metapathographies for this subgroup, considering these narratives

"not simple personal stories of illness but artful transformations of the genre, works whose authors, relying on the distinctive professional strengths at their disposal, write themselves out of illness and suffering and do so, finally, by looking past pathography itself" (Graham, 1997:73).

Graham's observations on the subject confirm the outstanding importance of taking into account, when authors of illness narratives are professional authors and intellectuals before receiving the diagnosis. When authors within this subgenre are professional writers and intellectuals, illness narratives addressing the experience of having a serious disease use specific narratological features to develop the story.

Although, medicine has appreciably improved since Karinthy's case in the first half of the $20^{\text {th }}$ century, and it is now offering new and more innovative techniques to treat patients of brain tumours, it often ignores many of the concerns and ne- 
eds of sick people related to the specific illness they are suffering and to their distinctive context. Confirming the aforementioned hypothesis of Bishop's article, the illness narratives that I take in my study reflect a specific harm and suffering of the brain tumour patients: the loss of their capacities and condition as professional writers. Thus, both Kartinthy's and Lubbock's novel reinforce previous studies on chronic illness as a biographical disruption, which can be traced as a constant motif in semi-structured interviews with patients (Bury, 1982), as well as in literary narrative works dealing with personal illness experiences (Cantabrana et al., 2016). Following narrative critic Rimmon-Kenan, the patient-writers in my corpus assume (whereas consciously or unconsciously) that the continuity of their past, present and future as active artistic subjects are destabilized by the disruption of a disease (Rimmon-Kenan, 2002:12) which turns them into ordinary laypersons and disconnects them from their self-image as writers during and after the disease. While describing other cases, Rimmon-Kenan suggests something that is particularly accurate to the narrative of biographical disruption (Bury, 1982), that both Karinthy and Lubbock have brought to their illness narratives: "reading and writing, a professional necessity as well as an existential passion, have become virtually impossible"(Rimmon-Kenan, 2002:10). In this sense, brain tumour and brain cancer impel new and relevant meanings in comparison to other diseases within illness narratives written by professional writers.

The selective nature for my study cases, A Journey Round My Skull and Until Further Notice, I Am Alive includes historiographical, geographical, thematic and literary aspects. As the aforementioned critical discussion has shown, they both fall into the illness narratives category and, hence, in the perspective of an actual patient. The general aim was to concentrate in brain tumour narratives written by professional authors, because of the quintessential symptomatic range of this disease that disqualifies the subject-patient as a writer and/or intellectual. The relevance of Karinthy's novel, A Journey Round my Skull, lies not only on the multiple narrative features of the text and on the focalization on his own illness process but also on its publication date. To that date (1939), complete autobiographical novels on illness experiences were not so frequent, especially in comparison to the nowadays growing number of autobiographical novels on serious illnesses, as cancer. As stated by Anne Hunsaker Hawkins, book-length pathographies are not very common "before 1950 and rarely found before 1900"(Hawkins, 1999b:3). On the other hand, Lubbock's novel has had a widely positive reception, in terms of literary quality it outstands from many other autobiographical novels on brain tumours, and is also nowadays a frequent reading recommendation for those subjects suf- 
fering from a brain tumour. ${ }^{1}$ While both together are European novels and refer to a contemporary world (from a symbolic point of view), their differences between geographical location and publication date (they are 75 years apart), enable a productive comparative analysis.

Our research question is: that narratives about brain tumours are a place where, while writing, professional authors resist the biographical and subjectivity fracture that happens after becoming patients of a disease, that normally deprives them of their creative and cognitive capacities. Instead of focusing on the health-disease pair, their writings are based on the realignment of their past and present identities (Rimmon-Kenan, 2002: 15-18), which are always linked to their images as authors, writers, and intellectuals. Therefore, the narrative searches for an image of themselves self as active artists, we may say, and not as patients. Focusing the analysis of the two novels on the autobiographical pact and on general narrative strategies and techniques, this article aims to examine the strong link between certain diseases' symptomatology and the narrative subjectivity built by patients. Finally, this comparative analysis is intended as a contribution from the field of literary studies to the understanding of subjectivity in writers as patients, whose narratives are not written to seek cure or even to search for a cause-reason to their disease, but rather to fight the loss of their creative identities and 'ipseities' (Derrida \& Bennington, 2009), which due to diagnoses, therapies, increasing symptoms and hospitalizations seem to be at stake.

\section{Frigyes Karinthy's A Journey Round my Skull (1939)}

Although many of us might not be very familiar with his name, Frigyes Karinthy was a very successful and prolific Hungarian author. He was born in Budapest in 1887 and died from a stroke in 1938, just one year before A Journey Round my Skull was published. As the title of the novel may anticipate, he was indeed a great admirer of Jules Verne. He published his first novel at the age of fifteen. He studied medicine and science at the University of Budapest, and after university he started working as a journalist while getting into the café society of the great Hungarian capital. Eventually, he wrote many other books and texts of different genres, including poetry, short stories, and theatrical pieces. Also, he became an influential person within the Hungarian intellectuality and got a name as a humourous writer.

The café society was the main milieu for the multiple changes and the Modernity rising in Europe at the end of the $19^{\text {th }}$ century and the beginning of the $20^{\text {th }}$ 
century. By the turn of the century, there were hundreds of cafés in Budapest, where writers, painters, philosophers and poets gathered around, sharing beverages while having lively conversations, and discussing the main agenda of intellectuality. These cafés were the infrastructure of modern cultural sociability. Although this type of social gathering at a public place was not formal, and only had as its main subject the discussion of current affairs while having a beverage, it was actually the place where most of the next-generation European artists were making a path. It is not a surprise, indeed, that Karinthy had recognized the very first symptoms of his disease while being at his favourite café. As he says in the first chapter of his novel The Invisible Train, he started having auditory hallucinations or sudden losses of consciousness: "And at that very moment the trains started. Punctually to the minute, at ten past seven, I heard the first one" (Karinthy et al., 2008:12). However, even without knowing that the source was a tumour he recognized the abnormality of the symptoms, and that they were not related to a psychological issue: "I could not have gone mad for, in that event, I should be incapable of diagnosing my case. Something else must be wrong." (Karinthy et al., 2008:14)

In addition to the hallucinatory train noises that became a constant presence, other manifestations of the tumour would get into his daily routine too. From this point, the narrative of Journey Round my Skull traces the path from the first symptoms of the brain tumour, through the different diagnoses, to the final verdict, including a highly complicated surgery in Sweden.

"The mirror opposite me seemed to move. Not more than an inch or two, then it hung still. [. . .] But what was happening now?

What was this - queer feeling - coming over me? The queerest thing was thatI didn't know what was queer. Perhaps there was nothing else queer about it. Yet I was conscious of something I had never known before, or rather I missed something that I had been accustomed to since I was first conscious of being alive, though I had never paid much heed to it. I had no headache, no pain of any kind, I heard no trains, my heart was perfectly normal. And yet [...]" (Karinthy et al., 2008:32-33).

Throughout the illness period as narrated in the novel, Karinthy persistently tries to hide his agony, the increasing disability marks generated by the specific location of the tumour, and he is frequently mistrustful towards his beloved ones and towards his medical practitioners. Not surprisingly, this attitude is not a resistance to the actual illness; he is not denying his ill condition. However, it seems as a 
resistance to being treated as a wounded and ill subject that has lost his most valuable identity trace, the one related to being an author as an (intellectual) authority in the first half of the 20th century. In another episode, again situated in a café, we reach a deeper understanding of how his narrative subjectivity as writer/patient is constantly negotiated in regard to his socially constructed image as a writer:

"[...] I took out my watch and laid it on the table.

'Give me some morphia,' I said in a calm, hostile, icy tone.

'You mustn't take morphia! You know perfectly well. The very idea! And what are you doing with that watch?'

'You will give me morphia within three minutes.'

They looked me uneasily up and down. No one moved. Three minutes went by. Then ten more. I slipped the watch calmly into my pocket and rose unsteadily to my feet.

'Then take me to the Fiakker Bar. They say it's a good show, and tonight I want to enjoy myself. '

The others jumped up with a feeling of relief.

I never confessed the secret to anyone, either then or afterwards. I had made up my mind at the end of those three minutes - for the first and last time in my lifethat if my headache had not stopped within the next ten I should throw myself under the nearest tram.

It never came out whether I should have kept to my resolve, for the pain left off with the suddenness of lightning." (Karinthy et al., 2008:132).

In Karinthy's novel, the space of the cafés should not be underestimated in terms of the construction of a narrative subjectivity linked to the artistic subject idea. In this particular passage, the patient/writer character is at the Café Paris in Vienna, where he goes to be diagnosed and treated of his pathology, surrounded by the social group to which he belongs: artists, intellectuals, journalists, and writers. By the end of the passage, we learn that his abrupt petition of morphia has to do with the aggravation of his symptoms. His headache was getting worse and worse to the point that he even wanted to die. Yet the narrative shows, that he interacted with his friends and acquaintances in an odd manner, without explaining what was going on. He would not share the truth of his condition with the surrounding subjects, and he finally resumed the interaction humorously asking to go to another bar. 
Acknowledging his symptoms in this particular public space, surrounded by this specific milieu, would have meant to accept the disruption, the narrative subjectivity disconnection that Rimmon-Kenan has noted down for illness narratives. Expressing his pain, manifesting his illness, would have meant to refuse his status as a writer, thinker and artist afflicted by spiritual and intellectual matters (not physical ones), a symbolic master narrative of his own, which apparently he was not ready to abandon. The level of the story puts together many other situations, where Karinthy' character masks the shortcomings and sufferings of the body with the redemption of the spirit and the mind:

"By now, I had learnt to interpret every hint afforded by the shifting of light and to complete the general effect from memory. I was getting used to this strange semi-darkness in which I lived, and I almost began to like it. I could still see the outline of figures fairly well, and my imagination supplied all the details, like a painter filling an empty frame. I tried to form a picture of any face I saw in front of me by observing the person's voice and movements. [ . . . I stood on the threshold of reality and imagination, and I began to doubt which was which. My bodily eye and my mind's eye were blending into one." (Karinthy et al., 2008:188-189)

These are Karinthy's words when the doctor stays staring at him, because he has finally realized that a brain tumour is causing his symptoms: "I had suddenly become a stranger to him" (Karinthy et al., 2008). It is not a negotiation between illness/ disability and health that is displayed in many sequences of the novel, but the negotiation between being a writer and being a subject suffering from a brain tumour; a negotiation against becoming a body of disease and losing his creative self.

\section{Tom Lubbock's Until further notice, I'm alive (2012)}

Tom Lubbock was a British writer, art critic and journalist. In the words of his wife's introduction to his last book:

"[...] a writer about art, a critic and an illustrator who worked with images, creating the collages which appeared weekly between 1999 and 2004 on the editorial page of The Independent, and intermittently since then" (Lubbock, 2012). 
To say that his novel Until further notice, I'm alive is about his fight against cancer is to come short at properly analysing this piece of illness narrative. Using the first person and chunks of a diary, Lubbock describes and follows each step of his suffering during the illness, specifically focusing on how he loses his ability to handle words, to create with words, and his inability to communicate with others. As Gregor Samsa at the beginning of Die Verwandlung (1915), finds himself suddenly transformed into another living being, one that feels strange to his own self; Tom Lubbock got unsettled about himself while realizing that his speech was "becoming a radical problem" since the diagnosis. A very talented and loquacious man found himself deprived not of life, because that is not what is actually missing in his novel, but of his more precious subjectivity trademark, his ability to express, describe and create beauty with words: "The good of the world includes my unique way of experiencing it, and for me that is almost all" (Lubbock, 2012).

Lubbock's original text was first published in an English newspaper, The $\mathrm{Ob}$ server, in 2010. The novel was also published in 2010, after Lubbock's death, and contains the original article along with entries from the journal that the author started writing shortly after his diagnosis and the realization that he was losing part of his verbal capacities. Framing a text with a note from a relative or close person to the deceased person is a common tool within narratives going through the final stretch of a person's life. In the case of Lubbock, this note is an introduction by Marion Coutts, his wife, who is constantly mentioned in her husband's narration, along with his little son, Eugene. Moreover, Lubbock's uses the first plural person in many passages, erasing the strong "I" typical of this type of narratives, and confirming the hardness of this process in his private circle his family.

Lubbock spends many pages dealing with a paradox, putting into words how he becomes deprived of his ability to formulate with words. He insists on perceiving this dysfunction as an abnormality turning him into a different subject; one who is no longer able to master a basic human function, the one of language:

"For me, no word comes without a prior thought. No sentence is generated without effort. No formulation is made automatically. I am faced practically and continually with a mystery that other people have no conception of, the mystery of the generation of speech" (Lubbock, 2012). 
In a few other passages, Lubbock's narrative displays this aspect of his disease, as a clear detachment from his prior self, as a writer who could master the art of language:

"Sometimes I feel that I am not quite well now, in relation to language, and then I want to know what is wrong; sometimes I feel I'm fine, and I want the results to be fine as before. I am as usual becoming fearful." (Lubbock, 2012).

The loss of language goes systematically together with the experience of othering from him (self).

Knowing its prognosis and life expectancy from the outset, Lubbock's text is constructed under the structural principle of the experience of a patient dying from a terminal illness. It builds a narrative line that has a theological orientation about life and death; it exhibits a painful but marked will to move forward to a recognized end that implies the death of the author and, within the narrative, the death of the character. However, this doesn't always work as clearly. The very same disruption of illness that tackles the past-present-future continuity projecting the narrative subjectivity only to the future, and to the end of disease, sometimes stops. This creates a new form of disruption of illness; a new unexpected pathway that must be accepted:

"When you get a cancer diagnosis, the story is expected to have two options. Either there is an ending with death. Or there is an overcoming. And both are satisfactory conclusions. But prolongation, unclear survival, is also a familiar narrative form. There is the shaggy-dog story that I and my family live in. Likewise, this hope for speech. The tale is spun out, with an ending wanting to be endlessly deferred." (Lubbock, 2012).

Although, the pause in the continuity to the future of the patient means attaining stability in terms of the disease, this equally affects our writer/patient subjectivity, who in these moments foresees the challenge of being present-oriented. Hence, this means perceiving as normal and constant the biographical and cognitive shifts that come with the illness. The new disruption in the past-present-future continuity brings about a new split in temporality, and creates what Marion Coutts defined in The Iceberg (2014), her own narrative of Lubbock's disease, as "Being stuck in the present" (Coutts, 2014). The present of the illness. 


\section{Subjectivity Disruption and Othering in Illness Narratives from Professional Writers}

"I cannot describe myself in words." (Coutts, 2014) These narratives significantly benefit from the question of loss of a subjectivity trait in relation to the artistic profession through the process of disease; the focus in this loss shoots and moves the narrative plotline; in a way which is much more powerful than making a detailed description of the physical pain suffered, or than delving into a death prognosis. Clearly, Karinthy as well as Lubbock, show in their narratives how the transition from being a writer to being a patient with a brain tumour implies a developing disability that deprives them of a subjectivity trademark. In this sense, their narratives confirm Bury's point on chronic illness as biographical disruption: "illness [...] is precisely that kind of experience where the structures of everyday life and the forms of knowledge which underpin them are disrupted" (Bury, 1982:169). As other shared narratological feature, both illness narratives discussed above achieve a textual empathy and not empathy based on proximity (Schmitt, 2017:121), or by identification with the life of the main character. Using various narrative resources, the textual empathy developed in the novels is based mainly on a narrative of an accomplished writer losing what he portrays as his artistic subjectivity while being a patient. Therefore, not only physical pain, fluctuating symptoms and uncertain outcomes, but also the question of why are not primarily focalised in both novels. On the contrary, the fluctuation of cognitive capacities that legitimize both subjects-protagonists as accomplished writers, how this disturbs the image of themselves, and the relation with the others take the narrative.

There is no essentialist view of the writer-patient identity in these narratives. On the contrary, as Rimmon-Kenan suggests, the "narrative identity" built in the text and the features deployed therein should be observed. In the case of Karinthy, the narrative builds a writer's identity that is socially perceived and recognized as such. The novel begins with the first symptoms in a relevant space for the modernist intellectual milieu and with an equivocal diagnostic process that lasts almost half of the novel, until the chapter "The Verdict". The disruption of the disease seems to inquire and put into play the narrative subjectivity of the writer that appears on the first pages. The manifestation of disease is the starting point from where the character/author/patient will try to negotiate between his (self) recognition of a writer's subjectivity and his patient status along the narrative. Jour- 
ney Round My Skull is riddled with notes, descriptions and comments on how the patient disguised his illness or avoided acknowledging his patient status within the presence of his illness. In spite of the fact, that ignoring, hiding and denying attitudes are a documented structural part of the classic sick-role behaviour (Bury, 1982), Karinthy's plotline should always be read as the search to reaffirm a narrative subjectivity as a socially recognized writer. In addition, the novel also portrays with extreme detail how the rest of the contemporary, and mainly Hungarian, society reflected and followed the process of Karinthy's illness, which is intended to be read as the illness of a recognized and relevant intellectual figure.

In the chapter Let His Bonds Be Loosened of Karinthy's novel, we find again the presence of this narrative configuration of disease in relation to the subjectivity of the accomplished and renowned author-intellectual. The writer/patient is at rest, after the successful completion of the brain tumour operation in the Swedish hospital, and he receives the visit of his doctor, Olivecrona, who asks him "Who are you in your own country?" (Karinthy et al., 2008:270). As reported to Karinthy, Olivecrona has received in recent hours a myriad of notes and calls from people in Hungary thanking him for saving this renowned patient. While in Sweden, Karinthy is a just another patient of a complicated medical case anonymized by the barriers of the hospital institution, in Hungary he is a well-recognized intellectual figure, whose ailment has become a national matter. In the same chapter, after the doctor leaves the room, the character-patient recites in a soft voice and with minimal modifications the poem "Die Heimkehr" (1824) by Heinrich Heine, which reaffirms his identity as a recognized writer, even when he is lying in bed after major surgery and some signs of disability due to the disease: "Ich bin ein ... Dichter/ Bekannt in ... Land/ Nennt man die besten Namen/ So wird auch der meine gennant." (Karinthy et al., 2008:271)2

On the other side, Lubbock begins his illness narrative from the beginning, which in medical terms is with the illness diagnosis in the first chapter, "A Piece of News". The main character/narrator wakes up in a hospital, after undergoing tests and scans that confirmed he had a stage four brain tumour. There is no narrative positioning on the level of the story as mainly a socially recognized writer, as there is in Karinthy's novel. Moreover, as we mentioned before, he sometimes uses a plural voice, displacing a strong individual voice as a writer, and he includes other people in the narrative constructions, creating a strong sense of sharing but in an intimate way. Instead, in Lubbock we found the exploration and inquiry around another element that has to do with a writer's narrative subjectivity: the 
loss of the ability to master every competence related to verbal language. This form of disability is what takes most of the narrative in Lubbock's novel, who is in a moving point of the book, after going under an operation notices that his speech and words are falling away. Accordingly, the twilight of the writing and verbal skills are coincidental with the last living moments of the writer/patient. And once again, as in Karinthy's case, we find poetry as a form of resistance of the narrative subjectivity in the most difficult time of the illness process:

"My true exit may be accompanied by no words at all, all gone.

The final thing. The illiterate. The dumb.

Speech?

Quien but still something?

Noises?

Nothing?

My body. My tree.

After that it becomes simply the world." (Lubbock, 2012)

These constructions of the narrative subjectivity identify as one of a writer with a brain tumour have different results at the story level. Karinthy chooses to construct a plotline that uncovers the constant need to battle the patient condition of the main character, reminding his position as a famous writer and hiding his symptoms on several occasions. In other words, Karinthy constructs a story that shows how the character/patient avoids confronting the "Altered state of consciousness" resulting from the brain tumour. Accordingly, the spaces where the plotline unwraps are mainly public, as the city cafés. Whereas Lubbock, who writes while the disease develops, puts the main symptoms in the foreground, especially those related to the confusion and loss of command and consciousness that Bishop pointed out in the aforementioned article. Lubbock constructs a narrative discourse that is, in fact, a resistance to the story level. While in the story level, Lubbock is losing his speech abilities, in the discourse level he is gaining words. Parallel to the patient's aphasia story, Lubbock creates a narrative text in the form of a novel, which is the actual confirmation of his narrative subjectivity as a writer, in spite of his symptoms due to the brain tumour. Consequently, the main spaces of Lubbock's illness narrative are private (as his own home) and internal (as his writing). 
The temporal perspectives used in these two novels are quite different. While Karinthy writes after his operation and recovery, Lubbock writes during his fatal disease process. In Lubbock's novel, the present of the narration is equivalent to the present of the experience. That's what Rimmon-Kenan calls the "simultaneous present" (Rimmon-Kenan, 2002:20) When taking together the illness narratives depicted in these novels, we can notice they have one point in common in terms of temporality: the disruption of disease in the previous present-past-future continuity produces a dislocation of the narrative identity in both writers and, thus, an absence of prolepsis and analepsis (Genette, 1980:40). This is, the narrators do not anticipate or evoke a healthy state that will occur after the main part of the story (the terminal disease process) ends. The disease casts a faint shadow on the identity as artists and intellectuals they had before the diagnosis, and they try bringing it to the present through narrative. Their narrative subjectivity as writers and the temporality used to build them are therefore dependent on one event: the emergence of the disease and its subsequent displacement. Moreover, if there is any analepsis and projection to an anachronistic past existing before the condition appeared, as Rimmon-Kenan points out, this appears in a non-central way (Rimmon-Kenan, 2002:20). The overwhelming present pervades it all, both in the story and in the discourse levels.

In practical terms, the chronic and terminal disease introduces patients to a completely new world that must be assimilated quickly, and has to do with the hospital apparatus: being taken care of by others, becoming the object of medicine and the health system. In symbolic terms, as we have already introduced in the texts of Karinthy and Lubbock, the patient's character is confronted with the self-consciousness of his own alterity that disrupts and dislocates a narrative subjectivity built as a writer. As patients, these characters face and turn into an otherness. That otherness is the one that confirms and remains the pre-existence of their selfhood, their 'ipseity', using a term Derrida takes from Heidegger:

"The definition that Heidegger then gives of the ipseity of the self-same (das "sich selbst") is linked to this effractive departure from self in order violently to break open, to capture, to tame (Ausbrechen, Umbrechen, Einfangen, Niederzwingen). It is through this violence that breaks open ground or path, captures, tames, that beings are discovered or revealed or unveiled." (Derrida \& Bennington, 2009:395) 
The writers' 'ipseity' appears disaggregated in the narrative of these novels by the appearance of a disease affecting the specific pillars of their creative and artistic lives, leading to their condition of patients and, accordingly, laymen. Derrida retains the sense of difference and 'ipseity' existing within the uniqueness or subjectivity of an individual's own perception of the Other and vice versa. For Derrida, the big question of 'ipseity' is intrinsically attached to sovereignty in terms of the possibility of selfhood. In this sense and in the framework of our study, the 'ipseity' is linked to the narrative identity of being a writer, and the otherness is linked to the narrative identity of being a patient. Beyond the State sovereignty, which is indeed of great importance for Derrida, we should consider these illness narratives as auto-positions of selfhood by the writer/patients, of their power to be singular selves.

\section{Concluding remarks}

In describing, discussing and comparing the illness narratives of Frigyes Karinthy and Tom Lubbock, I tried to contribute to the understanding of a distinctive group of cancer narratives, giving to contextual criteria and literary features a main role.

As a point of departure, I took the category of illness narratives originated by anthropologist Arthur Kleinman. Although I agree with both books, we are indeed confronted with illness narratives. I have found a main concern in my corpus that is not completely represented in Kleinman's observations. In his The IlIness Narratives: Suffering, Healing and the Human Condition (1988), Arthur Kleinman points out that the disease person and his/her social entourage almost always pose the question of why (Kleinman, 1988). As the analysis and discussion have shown, this is not a relevant question in the illness narratives of Karinthy and Lubbock. As shown in the analysis, when dealing with brain tumours, illness narratives compromised plenty narrative features that tend to stand out the literary and artistic subjectivity of the author. Thus, the question of who. Instead and following Bury's (1982) and Rimmon-Kenan's (2002) contributions, I have shown the disruption aspect of disease is central in these narratives in terms of the biographical traces of the implied subjects. On top, the narrative features of these ilIness narratives contribute to show not only that the disease does not write the subject-patients, but also that it does not prescribe the subject-writer to follow the 
normal pathways of dealing with a serious disease. Moreover, the narrative space becomes the place to negotiate a writer's subjectivity that resists with words and with an artistic production the progress of disease.

As readers of these two illness narratives, we tend to empathize with these authors/patients not mainly because of the physical suffering of the disease, but mostly because they delve into an internal reality conflict that rises after becoming a body of illness, a body of medicine and, particularly, a body of a disease that affects mainly the cognitive capacities related to being a writer and an intellectual. The narrative resources they both use tend to guide the reader in this direction. The question is: Who is the sovereign of an ill-body going through illness under modern biomedical treatments? Even more: Who is the sovereign of the ill-subject's narrative? Illness narratives of professional writers become a space for negotiating two narrative identities that are described as being incompatible in cases of brain tumour: the one of being a patient with endangered cognitive and creative abilities and the one of being a writer. And, as we have discussed, brain tumour disease symptoms play a central role in that interaction as a violent rupture recalling the sovereignty of the self as an artistic subject.

\section{Notes}

1. A quick internet research will confirm this. Many websites related to brain tumour organizations and institutions, as for instance the "Brain Tumour Research" website, list Lubbock's book within their recommendations.

2. The English translation of Karinthy's novel quotes Heine's verses in German as the transcription above. The complete text in German, without Karinthy's meanted omissions, is: "Ich bin ein deutscher Dichter/ Bekannt im deutschen Land/ Nennt man die besten Namen/ So wird auch der meine gennant" ["I'm a German poet/ In Germany well known/ Name the greatest names and/ You're sure to name my own" Heine \& Draper (1982:114)].

\section{References}

Bishop, M. G. (1994). The genius of disease. 3. A journey round my skull- Frigyes Karinthy. Journal of the Royal Society of Medicine, 87(1), 2-4.

Bradford, R. (2009). Life writing: Essays on autobiography, biography and literature edited by Richard Bradford. Basingstoke: Palgrave Macmillan.

Brody, H. (1987). Stories of sickness. New Haven: Yale University Press.

Bury, M. (1982). Chronic illness as biographical disruption. Sociology of health $\mathcal{E}$ illness, 4(2), 167-182. https://doi.org/10.1111/1467-9566.ep11339939

Cantabrana, B., González-Rodríguez, S., \& Hidalgo, A. (2016). Una literatura de la enfermedad y la muerte. Rev Med Cine, 12(1), 47-59.

Coutts, M. (2014). The Iceberg: A Memoir: Atlantic Books. 
Derrida, J., \& Bennington, G. (2009). The Beast and the Sovereign: University of Chicago Press. https://doi.org/10.7208/chicago/9780226144399.001.0001

Frank, A. W. (1995). The wounded storyteller: Body, illness and ethics / Arthur W. Frank. Chicago, London: University of Chicago Press. https://doi.org/10.7208/chicago/9780226260037.001.0001

Genette, G. (1980). Narrative Discourse: An essay in method. Ithaca: Cornell UP.

Graham, P. W. (1997). Metapathography: Three Unruly Texts. Literature and Medicine, 16(1), 70-87. https://doi.org/10.1353/lm.1997.0005

Hawkins, A. (1984). Two pathographies: A study in illness and literature. The Journal of medicine and philosophy, 9(3), 231-252. https://doi.org/10.1093/jmp/9.3.231

Hawkins, A. H. (1999a). Pathography: Patient narratives of illness. The Western journal of medicine, 171(2), 127-129.

Hawkins, A. H. (1999b). Reconstructing illness: Studies in pathography / Anne Hunsaker Hawkins. (2nd ed.). West Lafayette, Ind.: Purdue University Press.

Heine, H., \& Draper, H. (1982). The complete poems of Heinrich Heine: A modern English version / by Hal Draper. Boston, Mass.: Suhrkamp/Insel; Oxford Distributed by Oxford University Press.

Jurecic, A. (2012). Illness as narrative. Pittsburgh series in composition, literacy, and culture. Pittsburgh: University of Pittsburgh Press. https://doi.org/10.2307/j.ctt5hjr8p

Karinthy, F., Sacks, O., \& Barker, V. D. (2008). A Journey Round My Skull: New York Review Books.

Kleinman, A. (1988). The illness narratives: Suffering, healing, and the human condition. New York: Basic Books.

Lejeune, P., \& Eakin, P. J. (Eds.) (1988). On autobiography. Minneapolis: University of Minnesota Press.

Lubbock, T. (2012). Until Further Notice, I Am Alive: Granta Publications.

Preece, J., Finlay, F., \& Owen, R. J. (2007). New German literature: Life-writing and dialogue with the arts / Julian Preece, Frank Finlay and Ruth J. Owen (eds.). Leeds-Swansea colloquia on contemporary German literature, v. 1. Oxford: Peter Lang.

Rimmon-Kenan, S. (2002). The Story of »I«: Illness and Narrative Identity. Narrative, 10(1), 9-27. https://doi.org/10.1353/nar.2002.0006

Schmitt, A. (2017). The phenomenology of autobiography: Making it real. Routledge interdisciplinary perspectives on literature, 75. New York: Routledge Taylor \& Francis Group. https://doi.org/10.4324/9781315173504 